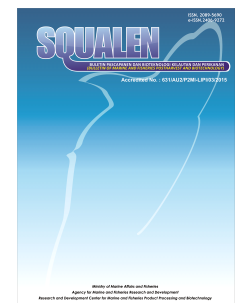

\title{
Concentration and Characteristic of Floating Plastic Debris in Jakarta Bay: a Preliminary Study
}

\author{
Dwiyitno Dwiyitno*, Fairdiana Andayani, Umi Anissah, Hedi Indra Januar, and Singgih Wibowo \\ Research Center for Marine and Fisheries Product Processing and Biotechnology, \\ JI. K.S. Tubun Petamburan VI, Jakarta, Indonesia 10260 \\ Article history: \\ Received: 28 April 2020; Revised: 20 July 2020; Accepted: 27 October 2020
}

\begin{abstract}
Marine debris, especially plastic debris, is becoming global awareness, including in Indonesia, due to the possible harmful effects on the environment and humans. The present study is the first assessment of the floating plastic debris in Jakarta Bay based on an at-sea survey. The study aimed to overview the accumulation of plastic debris in different zones (west, middle, and east) of the bay as the impact of wet and dry seasons. The results showed that plastic debris was found in most sampling stations with a maximum concentration of 10,300 and 7,400 items $/ \mathrm{km}^{2}$ in the wet and dry seasons, respectively. Based on the plastic types, polyethylene (PE), polypropylene (PP), and polystyrene (PS) were the main accumulated plastic debris in Jakarta Bay with a predominant macro size between 2.5 and $20 \mathrm{~cm}$. According to the plastic applications, packaging and consumer products were the majority of plastic debris at concentrations of $257-1,280$ items $/ \mathrm{km}^{2}$ and $936-983$ items $/ \mathrm{km}^{2}$ in the dry and wet season respectively. The spatial distribution of plastic litter in the observed surface water was correlated to temporal monsoon seasons rather than to the distribution of pollution source from rivers around the Jakarta Metropolitan Area. Moreover, the higher plastic concentration was found in the rainy west monsoon compared to that of the dry east monsoon.
\end{abstract}

Keywords: marine debris, plastic litter, Jakarta Bay, seasonal, spatial

\section{Introduction}

Marine debris, especially plastic debris, is becoming global awareness, including in Indonesia, due to the possible harmful effects on the environment and humans. United Nations Environment Programme (UNEP) (2005) defined marine debris as any persistent, manufactured, or processed solid material discarded, disposed-off, or abandoned in the marine and coastal environments. Eriksen et al. (2014) estimated more than 5.25 trillion pieces of plastic debris (over 250,000 tonnes) afloat across the sea. Additionally, Jambeck et al. (2015) revealed that plastic litter in the ocean during 2010 was approx. 4.8-12.7 million metric tonnes (Mt) and Indonesia is suggested as the second-largest producer of marine plastic debris after China, i.e., 0.48$1.29 \mathrm{million} \mathrm{Mt} / \mathrm{year}$. This problem is due to the increasing quantity of plastic applications, such as packaging, clothing, storage, transportation, construction, and various consumer product applications.
An estimated 6,300 Mt of plastic waste was generated by the end of 2015 (Geyer, Jambeck, \& Law, 2017). Out of these, $9 \%$ was recycled, $12 \%$ was incinerated, and $79 \%$ was accumulated in the environment. Furthermore, Boucher and Billard (2019) estimated 12 million tonnes/year of plastic in the marine ecosystem due to $3 \%$ worldwide leakage. They are predominantly composed of coastal mismanaged waste $(60-70 \%)$, and the rest are from either terrestrial mismanaged waste, plastic pellet, or fishing gear. Over the time and environmental exposures, the plastic litter will decompose at various rates depending on the polymer materials, density, type of functional group, hydrophobicity, and crystallinity (Wilkes \& Aristilde, 2017).

Regarding the marine litter composition, plastic debris has become the primary waste that accumulates on shorelines, ocean surface, and seafloor. Plastic pollution in marine ecosystems has been recognized as harmful. It has been recorded in

${ }^{*}$ Corresponding author.

E-mail: dwiyitno.brkp@kkp.go.id

Copyright @ 2020, Squalen BMFPB. Accreditation Number: 148/M/KPT/2020

DOI: http://dx.doi.org/10.15578/squalen.v15i3.462 
a wide range of marine organisms, including fish, molluscs, crustaceans, and mammals (De Witte et al., 2014; Devriese et al., 2015; Rochman et al., 2015). Microplastic, as a degradation product of macroplastic pollution, has shown possible ecotoxicological effects to marine organisms, such as weight loss, reduced feeding rate, increased phagocytic activity, transference to the Iysosomal system, bioaccumulation, and inhibition of acetylcholinesterase/ AChE activity (Avio, Gorbi, \& Regoli, 2015; Ribeiro et al., 2017).

A study concerning marine litter in Indonesia was started by Willoughby (1986) at Pulau Seribu, Jakarta. Afterward, several similar studies has been conducted in different regions. However, most of those studies were conducted based on beach surveys (Willoughby, 1986; Nash, 1992; Syakti et al., 2017). Recently, van Emmerik, Loozen, Oeveren, Buschman and Prinsen (2019) and Cordova and Nurhati (2019) have characterized and estimated the annual and monthly debris entering Jakarta Bay based on the input load through the rivers flowing to the bay. Accordingly, plastic debris is known as the major debris entering Jakarta Bay through rivers around Jakarta Metropolitan Area. However, a study on the plastic debris that covers the Jakarta Bay surface has not been established yet.

In general, there are three methods for marine litter monitoring, i.e., beach survey, at-sea survey, and estimation of litter input load (Rees \& Pond, 1995; Yamashita \& Tanimura, 2007; Hinojosa \& Thiel, 2009; Suaria \& Aliani, 2014; Marengo et al., 2020; Reinold, Herrera, Hernandez-Gonzales \& Gomez, 2020; Mansui et al., 2020). Beach survey is preferable due to the simplicity and relatively cost-effective approach to monitor marine litter. However, a survey at-sea is a direct survey applicable to avoid the complication and uncertainty of a beach survey. In the present study, we employ a modified net-based survey at-sea to collect floating litter directly from the surface water of Jakarta Bay. Jakarta Bay is vulnerable to environmental issues, especially related to the development of Jakarta as the capital city and its satellite cities. This preliminary study is important to overview the composition and concentration of floating plastic debris in Jakarta Bay based on spatial distribution collected in different seasons, which might be strongly affected by the Jakarta Metropolitan Area emission.

\section{Material and Methods}

\subsection{Study Location}

A sampling campaign was performed at 20 stations in Jakarta Bay to cover an area of about $514 \mathrm{~km}^{2}$ from Tanjung Pasir in the west to Tanjung Karawang in the

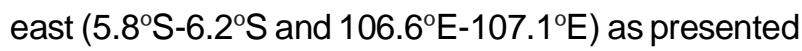
in Figure 1. Sampling points were stratified purposively based on terrestrial inputs into three zones (western, middle, and eastern) part of Jakarta Bay (Cordova \& Nurhati, 2019) and sea depth (Dwiyitno et al., 2015). These three zones were classified based on different terrestrial emission characteristics due to different land uses and population density. A sampling campaign was conducted during daylight from 07.00 to 12.00 pm, for three days in April 2018 to observe the impact of the wet season/west monsoon and in September 2018 for the impact of dry season/east monsoon. Based on daily rainfall data obtained from the Agency for Meteorology, Climatology, and Geophysics (BMKG) Indonesia, the dry season during 2018 was between

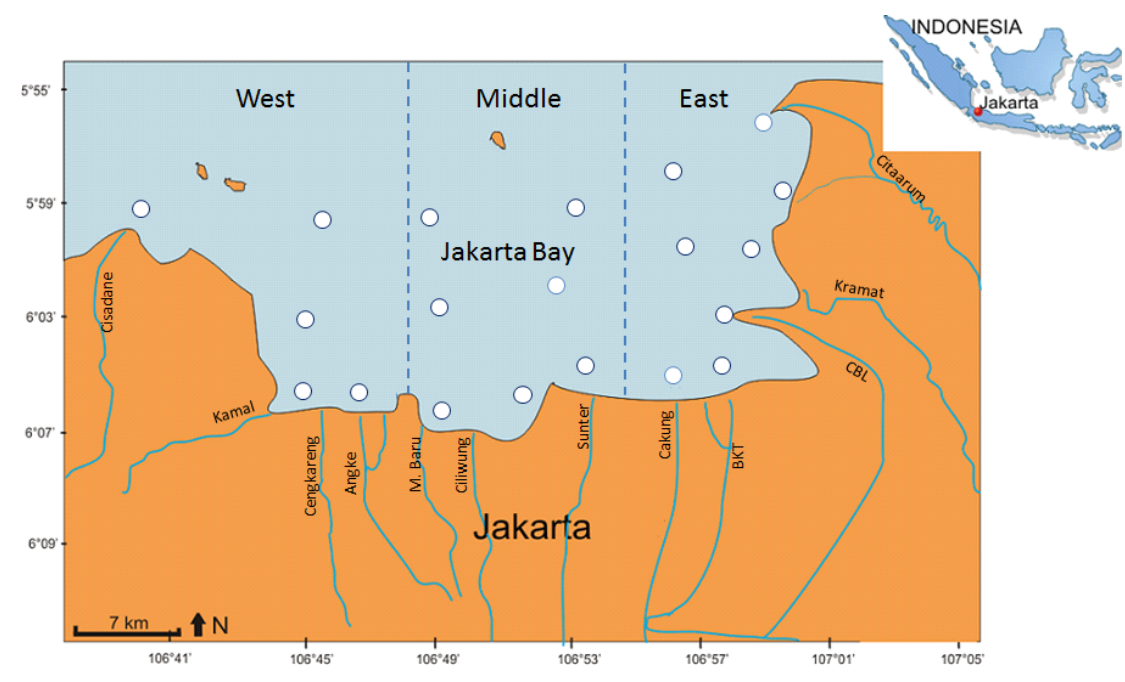

Figure 1. Overview of sampling stations for floating plastic debris study in Jakarta Bay 
May and October (precipitation $<100 \mathrm{~mm}$ ). Therefore the rest is considered as wet season.

\subsection{Samples Collection and Identification}

Marine litter was collected in Jakarta Bay following the at-sea survey approaches (adapted from Yamashita \& Tanimura, 2007), with a sampling area of approx. $100 \mathrm{~m} \times 100 \mathrm{~m}$, adopted from $1 \mathrm{~km} \times 1 \mathrm{~km}$ square of guideline introduced by UNEP-IMO (2007). Floating litter was directly taken on board from the sea surface $(0-20 \mathrm{~cm})$ with a $5 \mathrm{~mm}$ mesh hand scoop net and an opening diameter of $40 \mathrm{~cm}$. Collecting time was influenced by the concentration of the litter, in general, it took approx. 5 mins/station. This is a modified approach of the net-based procedure originally using manta, neuston, or plankton nets (Yamashita \& Tanimura, 2007; Law et al., 2010; Law et al., 2014).

Other relevant parameters included geo-position, and weather conditions were recorded. All samples were transported to the laboratory in Jakarta for further plastic litter identification. Prior to identification, all plastic debris were cleaned, sun-dried, sorted, weighed, measured, and further classified based on the plastic material, i.e., PE (High Density Polyethylene (HDPE), Low Density Polyethylene (LDPE)), PP, PET, PS, PVC, and other materials. All meso-plastic and macro plastic litter more than $5 \mathrm{~mm}$ in size were counted and weighed (Axelsson \& van Sebille, 2017). Identification was also categorized based on common utilization such as packaging, consumer product, fishing gear, clothes/textile, and other applications (Geyer et al., 2017; Anonymous, 2018). Data of plastic litter were then tabulated based on the spatial and temporal distributions as well as plastic profile (item abundance and weight) related to the plastic category and common utilization.

\subsection{Data Processing}

All data of plastic litter distribution were tabulated and presented into a graphical map. GPS position of sampling station in Jakarta Bay was overlaid on the map taken from Google Maps with EasyGPS software. Statistical analysis of non-parametric was performed to define the difference of plastic litter distribution between spatial (location) and temporal (season). Moreover, multivariate discriminant analysis was also applied to define the interaction between spatial (location) and temporal (season) of debris distribution in the study area. SPSS V15.0 Software and Past Statistical Software V3.08 (Hammer, Harper, \& Ryan, 2001) were employed for these analyses.

\section{Results and Discussion}

\subsection{Plastic Litter Distribution and Composition}

The result showed that plastic debris was found in most sampling stations in Jakarta Bay, i.e., 13 out of 20 stations (65\%) in the wet season and $70 \%$ in the dry season (Figures 2 and 3). However, since the samples were not collected during the whole season, this result may not reflect the seasonal debris profile. Based on the item number (Figure 2), plastic litter density in Jakarta Bay in the wet season was between 1 and 103 items/station of $100 \times 100 \mathrm{~m}^{2}(100-10,300$ items $/ \mathrm{km}^{2}$ ), while in the dry season was between 100 $-7,400$ items $/ \mathrm{km}^{2}$. PE was found as the most dominant plastic material identified in Jakarta Bay based on item number, followed by PS and PP. PE was distributed in all observed stations in the dry season at a concentration of $100-6,400 \mathrm{items} / \mathrm{km}^{2}$ and in $87 \%$ of observed stations at a concentration of 100-1,200 items $/ \mathrm{km}^{2}$ in the wet season (Figures $2 \mathrm{a}$ and $2 \mathrm{~b}$ ). Similarly, PS was found relatively higher in the dry season $\left(200-6,800\right.$ items $\left./ \mathrm{km}^{2}\right)$ compared to that in the wet season (100-1,200 items $\left./ \mathrm{km}^{2}\right)$. In contrast to PE, other materials (PP, PET, and PVC) were less distributed in Jakarta Bay, both in wet and dry seasons. PP, PET, and PVC were identified at a concentration of 100-2,100;200-400 and 100-1,000 items $/ \mathrm{km}^{2}$ respectively in the wet season, while in the dry season were only 200-500; 100 ; and 0 items/ $\mathrm{km}^{2}$, respectively.

Since our method was relatively simple in comparison to the common at-sea survey, such as net-based survey using neuston net or pelagic trawl (Yamashita \& Tanimura, 2007; Grøsvik et al., 2018) also a visual survey from the boat or aircraft (Hinojosa \& Thiel, 2009; Suaria \& Aliani, 2014), the litter density of Jakarta Bay from the present study might be underestimated. This is due to the sampling device limits to collect objects less than $40 \mathrm{~cm}$. Additionally, some mesoplastic objects $(<2.5 \mathrm{~cm})$ may not be collected because they are too small in size. However, we assume that mesoplastic contribution was relatively minor in weight as the minor size was dominated by styrofoam fragments with relatively low density $\left(1.05 \mathrm{~g} / \mathrm{cm}^{3}\right)$. Another limitation of this method is the number of 20 sampling stations covering 514 $\mathrm{km}^{2}$ of Jakarta Bay, resulting the distance among stations was far apart, ranging from $3-5 \mathrm{~km}$. However, the stations were stratified distributed in the whole area of Jakarta Bay. Thereafter, we presume that the plastic debris composition in the present study could overview the general composition in Jakarta Bay. So 


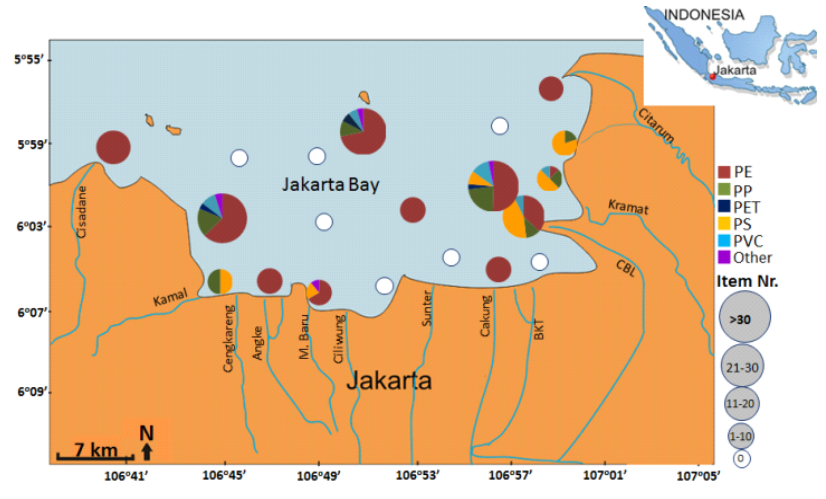

(a)

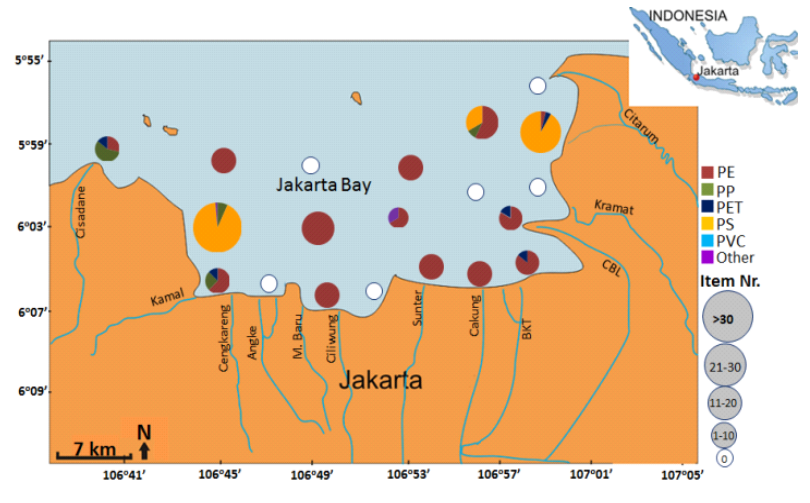

(b)

Figure 2. Plastic litter density (per $100 \times 100 \mathrm{~m}^{2}$ ) of Jakarta Bay based on the category in the wet season (a), and the dry season (b)

far, the only study of floating litter based on an at-sea survey in Indonesian water was reported by Uneputty and Evans (1997). They estimated floating litter across Ambon Bay from the north to the south shore based on a sampling size of $80 \mathrm{~m}^{2}$. The result showed that some marine litter in Ambon Bay was similar to that in Jakarta Bay, i.e., mainly composed of plastic bottles, drink cans, plastic bags, and polystyrene pieces at a concentration of 0.05-8.6 items $/ \mathrm{m}^{2}$. However, the study did not classify in details the plastic litter in Ambon Bay based on material category and common utilization.

The results of plastic composition in the present study are in accordance with those observed at four main rivers in Jakarta city by earlier studies. Van Emmerik et al. (2019) reported that PS and multilayer plastic of PE and PP were the most dominant debris at rivers of Banjir Kanal Barat (BKB) Grogol, Cengkareng Kapuk, Ciliwung-MT Haryono, and BKB Angke. Styrofoam was also found as the majority of plastic debris at nine rivers flowing to Jakarta Bay through Jakarta city and boundary regions (Tangerang and Bekasi), as reported by Cordova and Nurhati (2019). Accordingly, $57,668 \pm 16,559$ plastic items/day was estimated to enter Jakarta Bay through those rivers. Further dominant debris included plastic wraps, plastic bottles/cups, and plastic cover, possibly composed of PE, PP, or PET.

Identification of floating plastic weight at Jakarta Bay was measured ranged from $0.05-15.83 \mathrm{~kg}$ of dry weight $/ \mathrm{km}^{2}$ (average $2.79 \mathrm{~kg} / \mathrm{km}^{2}$ ) in the wet season and ranged from $0.01-4.55 \mathrm{~kg}$ of dry weight $/ \mathrm{km}^{2}$ (average $1.65 \mathrm{~kg} / \mathrm{km}^{2}$ ) in the dry season. Similar to the density profile, $\mathrm{PE}$ and PP were the most dominant floating plastics in Jakarta Bay based on litter weight (Figure 3). On the contrary, in this study, PVC and PET mass were more dominant than PS mass due to differences in their material densities. PS density is relatively low $\left(1.05 \mathrm{~g} / \mathrm{cm}^{3}\right)$ and therefore, comparatively easier to disperse on the surface water than PVC (1.44 $\left.\mathrm{g} / \mathrm{cm}^{3}\right)$ and PET $\left(1.39 \mathrm{~g} / \mathrm{cm}^{3}\right)$. Similar to the earlier study, polyolefin (PE, PP) and multilayer plastic were the most dominant plastic litter in the rivers flowing to Jakarta Bay, as reported by Van Emmerik et al.(2019). Moreover, Cordova and Nurhati (2019) also reported that plastic materials of bottles, cups, covers, and wrap were among the predominant debris at nine rivers entering Jakarta Bay, together with rubber-plastic mixed materials of shoes, sandals, and gloves.

$P E$ is the essential plastic material, mainly applied in the packaging of food products and other daily uses. This fact is in line with the result of plastic litter classification based on utilization, as presented in Figure 4a. Considering the results, plastic litter in Jakarta Bay primarily was from packaging and consumer product application. Plastic packaging and consumer materials were identified in the wet season at a concentration of 100-7,600 and 100-4,600 items/ $\mathrm{km}^{2}$, while in the dry season were $100-600$, and 1006,900 items $/ \mathrm{km}^{2}$. They comprise food packaging, plastic bags, single-use packaging of personal products, plastic utensils, straws, styrofoam for electronic packaging, and plastic toys. Additionally, plastic liter from fishing gear (nylon), as well as clothing and textile (footwear and baby diapers), were only found in wet season sampling with less concentration $\left(100-200\right.$ items $\left./ \mathrm{km}^{2}\right)$ than others materials. Plastic bags/packaging, plastic bottles or consumer products, and textiles are the prominent and among the first plastic objects produced and massively used globally (Geyer et al., 2017; Clapp \& Swanston, 2009; Dauvergne, 2018).

Floating plastic litter in Jakarta Bay based on size category showed that the most dominant size was 


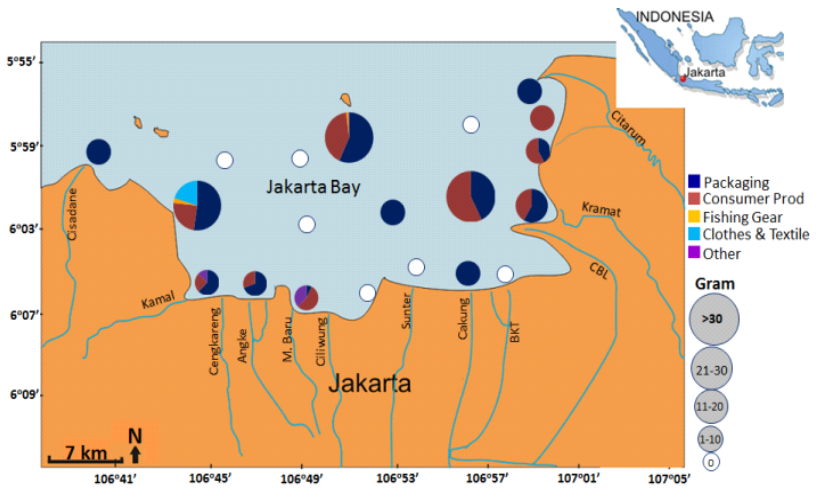

(a)

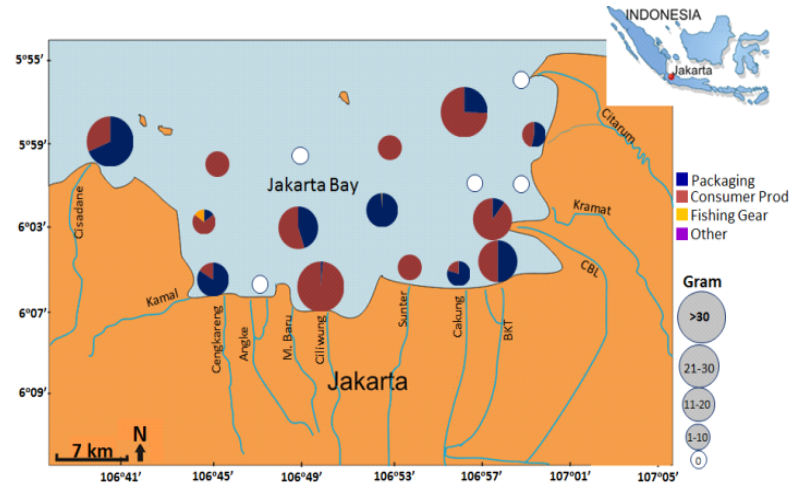

(b)

Figure 3. Distribution of plastic litter weight (per $\left.100 \times 100 \mathrm{~m}^{2}\right)$ in Jakarta Bay based on utilization in the wet season (a), and the dry season (b)

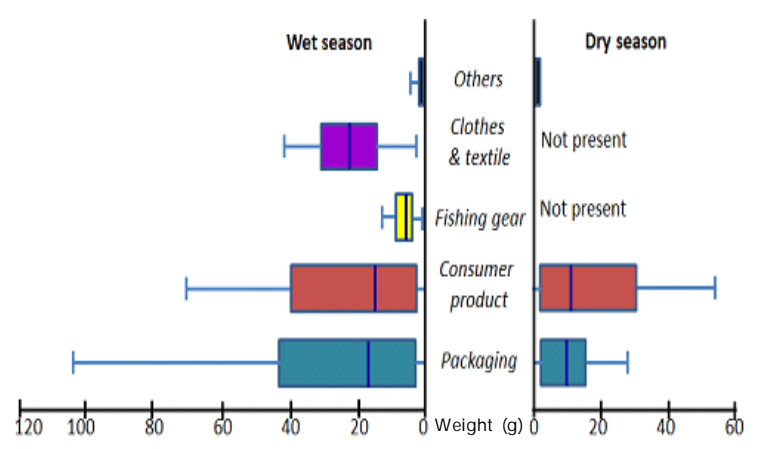

(a)

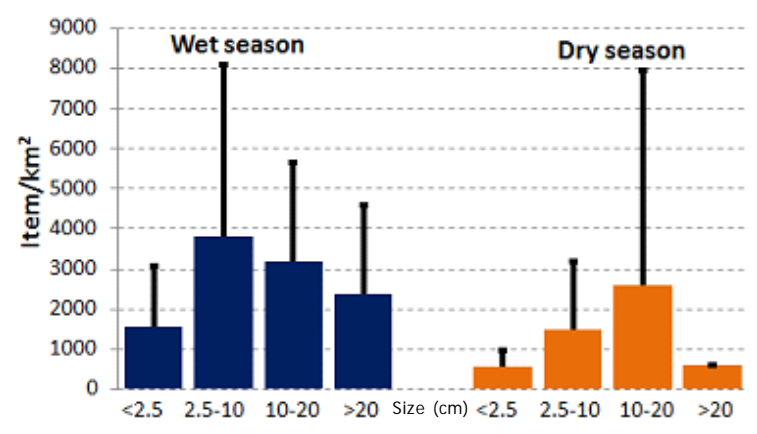

(b)

Figure 4. Temporal plastic litter mass in Jakarta Bay based on (a) utilization and (b) distribution of plastic size (<2.5 cm: meso-plastic; $\geq 2.5 \mathrm{~cm}$ : macro-plastic)

macroplastic between 2.5 and $20 \mathrm{~cm}$ at a concentration ranged from $100-6,600$ items $/ \mathrm{km}^{2}$ (average 1,642 items $/ \mathrm{km}^{2}$ ) in the wet season and 1006,900 items $/ \mathrm{km}^{2}$ (average 1,100 items $/ \mathrm{km}^{2}$ ) in the dry season (Figure $4 b$ ). This fact reflects the most dominant plastic litter was packaging food products, detergent, and other products such as plastic bottles, cups, and utensils, as presented in Figure 4a. Furthermore, plastics over $20 \mathrm{~cm}$ was mainly composed of plastic bags, ropes, fishing gears, and straws. In comparison, the mesoplastic less than 2.5 $\mathrm{cm}$ was dominated by pieces of styrofoam and PE or PP plastics, which are also identified mostly in rivers (Cordova \& Nurhati, 2019).

\subsection{Spatial and Temporal Distribution}

Spatial analysis of floating plastic showed that the western part of Jakarta Bay is the highest accumulating region in Jakarta Bay based on weight, especially in the wet season, followed by the eastern part (Figure 5b). Meanwhile, the least concentrated region was the middle zone (Figure 5 ). This could indicate the different input load of debris through Jakarta rivers due to either debris accumulation or river debit. Cordova and Nurhati (2019) identified two main rivers with significant discard of plastic debris to Jakarta Bay are Bekasi River in the eastern part (Bekasi Region) and Dadap River in the western part (Tangerang Regency) at an amount of $2.61 \pm 1.31$ tonnes $(31 \%)$ and $2.15 \pm 0.88$ tonnes $(26 \%)$ per day, respectively. Other study reported that plastic emission through Angke River (Banjir Kanal Barat) was estimated as 1.5 tonnes/day. The plastic emission was double than the plastic concentration of Banjir Kanal Timur (0.7 tonnes/day) and PesanggrahanKapuk River ( 0.5 tonnes/day), as reported by Van Emmerik et al. (2019). Nevertheless, plastic emission through Cisadane and Citarum Rivers was not measured by these studies. Cisadane and Citarum are among the main rivers to Jakarta Bay with a 


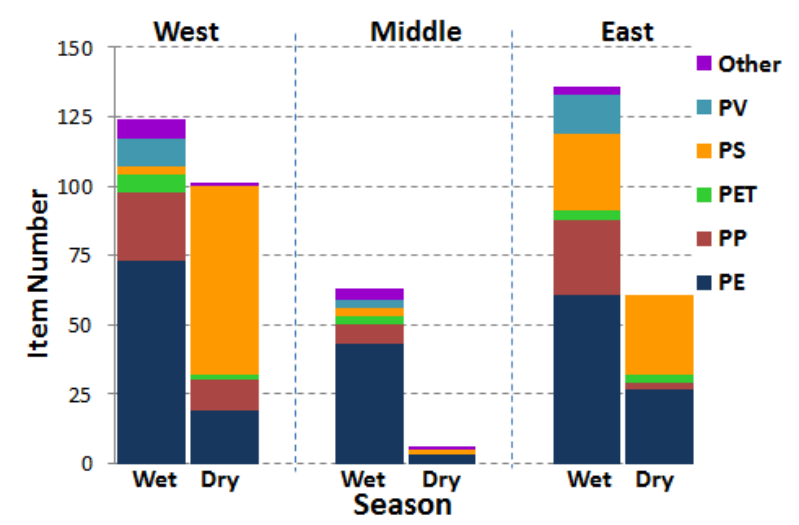

(a)

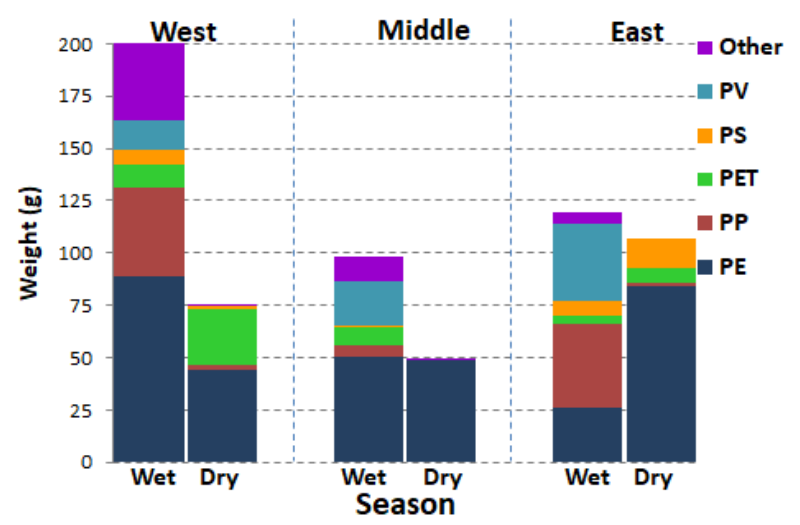

(b)

Figure 5. Spatial distribution of plastic litter in west, middle and east zone of Jakarta Bay based on density (a); and based on weight (b) per $100 \times 100 \mathrm{~m}^{2}$

significant debit of $40-120 \mathrm{~m}^{3} / \mathrm{s}$ and $3-370 \mathrm{~m}^{3} / \mathrm{s}$, respectively (Hidayat, Murtilaksono, Wahjunie, \& Panuju, 2013; Khoir, Rohmah, \& Nuryadi, 2018).

Population density and different land-use may contribute to the different emission of plastic debris from the Jakarta Metropolitan Regions to Jakarta Bay. Takarina and Adiwibowo (2011) suggested the western and eastern parts of the bay are generally used for industrial and agricultural activities, while the middle of Jakarta is predominantly used for domestic residential. Consequently, the rivers flow through these zones may deliver different emission types and densities, including solid waste, into Jakarta Bay. Domestic residential may suggest as the major source of plastic litter in Jakarta Bay, as our study showed that plastic litter was mainly derived from domestic applications (packaging, consumer product, and textile). According to the previous study, domestic waste typically contributes to $60-75 \%$ of solid waste in Indonesia, mostly plastic bags and diapers, which account for $21.6 \%$ and $12.9 \%$, respectively (Anonymous, 2018). However, the oceanic dynamic may also contribute to the accumulation pattern of plastic debris in different zones of Jakarta Bay.

Temporally, plastic litter density in Jakarta Bay during the wet season was higher than that during the dry season. This fact supports the possible land-based leakage of solid waste through 13 main rivers at the wet season as the main marine debris source in Jakarta Bay (Anonymous, 2018; Van Emmerik et al., 2019; Cordova \& Nurhati, 2019). The plastic debris derived from packaging, consumer product, clothes/ textile, and fishing gear was detected significantly higher in April of the wet western monsoon season (Figure 5a). Earlier studies conducted in rivers around Jakarta Bay also indicated that terrestrial debris was essentially delivered during the wet season, mainly between December-February (Cordova \& Nurhati, 2019). Moreover, the higher accumulation of plastic litter in rainy western monsoon may relate to the higher water volume from terrestrial rivers that bring plastics litter from the city to the bay. A significant fluctuation of river debit flowing to Jakarta Bay between dry and wet season was reported by Budiyono, Aerts, Tollenaar, and Ward (2015); Van Emmerik et al. (2019), as well as Cordova and Nurhati (2019).

Statistical multivariate discriminant analysis suggests that the spatial-temporal season significantly affects floating plastic distribution in Jakarta Bay (Figure 6). However, the distribution of plastic litter on the surface water of Jakarta Bay tends to be significantly affected by temporal monsoon season rather than the spatial location of the source. All plastic debris density vector was directed into the west and east regions, indicating the accumulation of plastic debris in the west and east regions of the bay was higher compared to those of the middle zone. Moreover, a different pattern of plastic density was also showed between seasons. Rainy west monsoon season was characterized by higher accumulations of PP, PVC, and $P E$ than those in dry east monsoon season. Meanwhile, the accumulation of PP, PVC, and PE was vice versa.

The different sea current may affect the higher plastic debris accumulation in the eastern zone than those in the western zone, and vice versa during the dry season. Also in the western zone during the dry season. Adhyatma and Atmadipoera (2018) stated that during the west monsoon wet season, the Jakarta Bay water flows eastward relatively faster than during the east monsoon dry season. A previous simulation study showed that tidal moved from the east to the west in the eastern monsoon season. Moreover, plastic litter was higher in the western area, meanwhile 


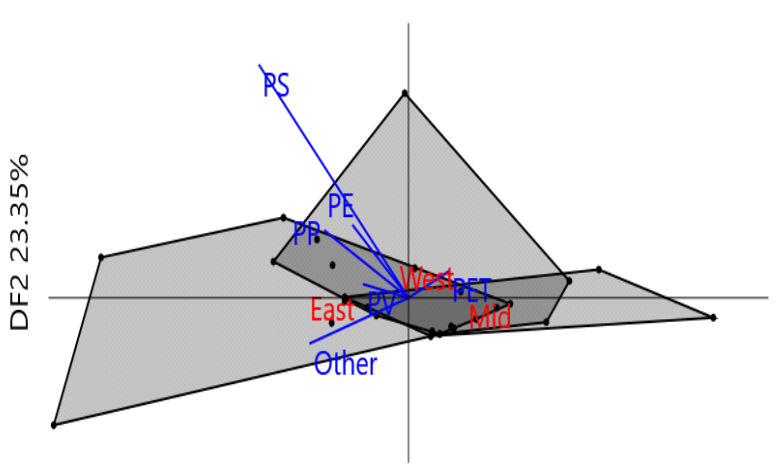

DF1 $76.65 \%$

(a)

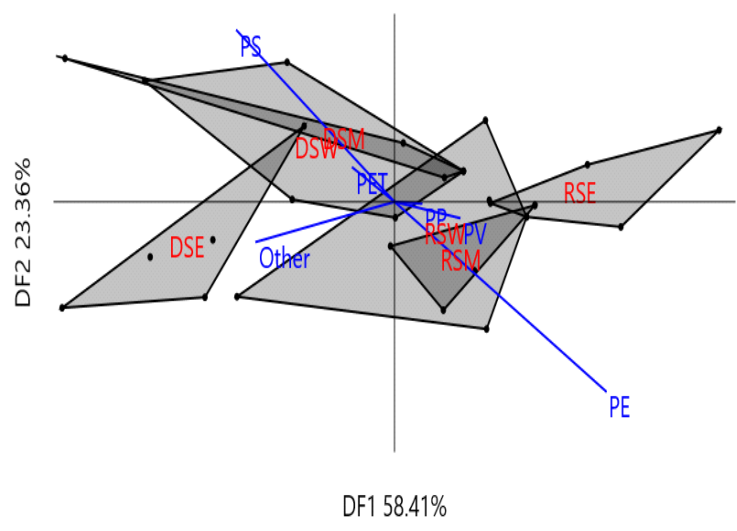

(b)

Figure 6. The statistical multivariate discriminant of plastic debris density in Jakarta Bay based on (a) spatial (western, middle, and eastern zone) and (b) temporal (rainy west monsoon and dry east monsoon) (RSW: rainy season in the west zone; RSW: rainy season in mid-zone; RSE: rainy season in the east zone; DSW: the dry season in the west zone; DSW: the dry season in mid-zone; DSE: the dry season in the east zone)

in the western monsoon season was vice versa (Jasmin et al., 2019). Our results strengthened this simulation that plastic litter was primarily accumulated in the eastern and western sides instead of in the middle side. Nonetheless, the middle side of Jakarta area is suggested as the major source of plastic litter, as reported by van Emmerik et al. (2019).

In comparison to other coastal waters, the accumulation of floating plastic in Jakarta Bay in the present study was relatively high as the density was between 7,400 and 10,304 items $/ \mathrm{km}^{2}$. This concentration is the highest compared to the maximum concentration in other studies based on macro sizes, such as Malacca Strait $\left(579\right.$ items $\left./ \mathrm{km}^{2}\right)$, North Pacific (459 items $\left./ \mathrm{km}^{2}\right)$, Southern Chile (10-250 item $\left./ \mathrm{km}^{2}\right)$, Mediterranean Sea (11-195 item $\left./ \mathrm{km}^{2}\right)$ and North Sea $\left(0.3-17\right.$ item $\left./ \mathrm{km}^{2}\right)$ as reported by Hinojosa and Thiel (2009); Thiel et al. (2011); Titmus and Hyrenbach (2011); Ryan (2013); as well as Suaria and Aliani (2014). The higher concentrations of floating plastic debris than that of Jakarta Bay were reported from Cap Corse, Mediterranean Sea $(11,688-27,027$ item $\left./ \mathrm{km}^{2}\right)$, and Australian Sea (15,500-23,611 item/ $\mathrm{km}^{2}$ ), which were also reported by Marengo et al. (2020) and Reisser et al. (2013) respectively, based on micro-, meso-, and macro-plastics size.

\section{Conclusion}

Floating plastic debris was found in the most sampling stations in Jakarta Bay at concentration of
$7,400-10,304$ items $/ \mathrm{km}^{2}$ in the dry season and wet season, respectively. The most dominant plastic litter was from packaging and consumer product applications. The collected plastic debris was classified as PP, PE, PS, and PV, of which $2.5-20 \mathrm{~cm}$ macroplastic were the most dominant size. The distribution of floating plastic in Jakarta Bay indicated the different emission load from different rivers as the main source of accumulation. However, the distribution is more related to the temporal monsoon season than the spatial location of the plastic source. Temporarily, the plastic density in Jakarta Bay accumulated higher in the rainy western monsoon season, than that of the dry season.Compared to other regions, the concentration of floating plastic in Jakarta Bay was relatively high. Therefore, the authority has to take strategic actions and assess the sustainable impact of the ecosystem. Moreover, a further assessment with a standardized protocol such as visual survey or surface water sampling with manta net or neuston trawl is suggested to provide a better estimation.

\section{Acknowledgments}

This research was supported by the Indonesian Research and Development Center for Marine and Fisheries Product Processing and Biotechnology, Ministry of Marine Affairs and Fisheries (Grant Number SP DIPA-032.12.2.403835/2018). All authors contributed equally in this work. 


\section{References}

Adhyatma, D. \& Atmadipoera, A.S. (2018). Impact of reclamation on monsoonal circulation changes in Jakarta Bay. MSTBIHO IOP Publishing IOP Conf. Series: Earth and Environmental Science 176(012008):1-12. doi:10.1088/1755-1315/176/1/ 012008

Anonymous. (2018). Indonesia Marine Debris Hotspot. Rapid Assessment Synthesis Report. World Bank Group, Indonesian Ministry Coordinator of Maritime, Embassy of Denmark, Royal Norwegian Embassy. $42 p$

Avio, C. G., Gorbi, S., \& Regoli, F. (2015). Experimental development of a new protocol for extraction and characterization of microplastics in fish tissues: First observations in commercial species from Adriatic Sea. Marine Environmental Research, 111,18-26. doi: 10.1016/j.marenvres.2015.06.014

Axelsson, C., \& van Sebille, E. (2017). Prevention through policy: Urban macroplastic leakages to the marine environment during extreme rainfall events. Marine Pollution Bulletin, 124, 211-227. doi: 10.1016/ j.marpolbul.2017.07.024

Boucher, J., \& Billard, G. (2019). The challenges of measuring plastic pollution, Field Actions Science Reports, Special Issue 19, 68-75. http:// journals.openedition.org/factsreports/5319.

Budiyono, Y., Aerts, J. C. J. H., Tollenaar, D., \& Ward, P. (2015). River flood risk in Jakarta under scenarios of future change. Natural Hazards and Earth System Sciences Discussions, 3(7), 4435-4478. doi: 10.5194/ nhessd-3-4435-2015

Clapp, J., \& Swanston, L. (2009). Doing away with plastic shopping bags: International patterns of norm emergence and policy implementation. Environmental Politics, 18(3), 315-332. doi:10.1080/ 09644010902823717

Cordova, M. R., \& Nurhati, I. S. (2019). Major sources and monthly variations in the release of land-derived marine debris from the Greater Jakarta area, Indonesia. Scientific Reports, 9(1), 1-8. doi: 10.1038/ s41598-019-55065-2

Dauvergne, P. (2018). The power of environmental norms: Marine plastic pollution and the politics of microbeads. Environmental Politics, 27(4),579597.doi: 10.1080/09644016.2018.1449090

De Witte, B., Devriese, L., Bekaert, K., Hoffman, S., Vandermeersch, G., Cooreman, K., \& Robbens, J. (2014). Quality assessment of the blue mussel (Mytilus edulis): comparison between commercial and wild types. Marine Pollution Bulletin, 85(1), 146155. doi: 10.1016/j.marpolbul.2014.06.006

Devriese, L. I., van der Meulen, M. D., Maes, T., Bekaert, K., Paul-Pont, I., Frère, L., Robbens, J., \& Vethaak, A. D. (2015). Microplastic contamination in brown shrimp (Crangon crangon, Linn. 1758) from coastal waters of the Southern North Sea and Channel area. Marine Pollution Bulletin, 98(1), 179-187. doi: 10.1016/j.marpolbul.2015.06.051
Dwiyitno, D., Dsikowitzky, L., Andarwulan, N., Irianto, H. E., Lioe, H. N., Ariyani, F., \& Schwarzbauer. J. (2015). Non Target Screening Approach for the Identification of Persistent and Emerging Organic Contaminants Related to Sediment and Seafood Samples from Jakarta Bay. Squalen Bulletin of Marine and Fisheries. Postharvest and Biotechnology., 10(3), 141-157. doi: 10.15578/squalen.v10i3.175

Eriksen, M., Lebreton, L. C. M., Carson, H. S., Thiel, M., Moore, C. J., Borerro, J. C., ... Reisser, J. (2014). Plastic pollution in the world's oceans: More than 5 trillion plastic pieces weighing over 250,000 tons afloat at sea. PLoS ONE, 9, e111913. doi: 10.1371/ journal.pone.0111913

Geyer, R., Jambeck, J. R., \& Law, K.L. (2017). Production, use, and fate of all plastics ever made. Science Advances, 3(7), e1700782, 1-5. doi: 10.1126/ sciadv. 1700782

Grøsvik, B. E., Prokhorova, T., Eriksen, E., Krivosheya, P., Horneland, P. A., \& Prozorkevich, D. (2018). Assessment of marine litter in the Barents Sea, a part of the joint Norwegian-Russian ecosystem survey. Frontiers in Marine Science, 5, 1-11. doi: 10.3389/fmars.2018.00072

Hammer, O., Harper, D. A. T., \& Ryan, P. D. (2001). Past: palaentological statistics software package for education and data analysis. Palaentologia Electronica, 4(1), 1-9.

Hidayat, Y., Murtilaksono, K., Wahjunie, E. D., \& Panuju, D. R. (2013). Pencirian Debit Aliran Sungai Citarum Hulu. Jurnal IImu Pertanian Indonesia (JIPI), 18(2), 109-114.

Hinojosa, I. A., \& Thiel, M. (2009). Floating marine debris in fjords, gulfs and channels of Southern Chile. Marine Pollution Bulletin, 58(3), 341-50. doi: 10.1016/ j.marpolbul.2008.10.020

Jambeck, J. R., Geyer, R., Wilcox, C., Siegler, T. R., Perryman, M., Andrady, A., ... Law, K. L. (2015). Plastic waste inputs from land into the ocean. Science, 347, 768-771. doi: 10.1126/science.1260352

Jasmin, H. H., Purba, N. P., Harahap, S. A., Pranowo, W. S., Syamsudin, M. L., \& Faizala, I. (2019). The model of macro debris transport before reclamation and in existing condition in Jakarta Bay. Jurnal IImu dan Teknologi Kelautan Tropis, 11(1), 131-140. doi: 10.29244/jitkt.v11i1.24777

Khoir, A. N., Rohmah, M., \& Nuryadi. (2018). Correlation analysis of Standardized Precipitation Index (SPI) for the water debit and level of the Cisadane River during El Niño and La Niña years. IOP Conference Series: Earth and Environmental Science. 139(1): 012022 doi: 10.1088/1755-1315/139/1/012022

Law, K. L., Moret-Ferguson, S., Maximenko, N. A., Proskurowski, G., Peacock, E. E., Hafner, J., \& Reddy, C.M., (2010). Plastic accumulation in the North Atlantic subtropical gyre. Science 329, 1185-1188. doi: 10.1126/science. 1192321

Law, K. L., Morét-Ferguson, S. E., Goodwin, D. D., Zettler, E. R., DeForce, E., Kukulka, T. \& Proskurowski, G. (2014). Distribution of surface plastic debris in the 
eastern pacific ocean from an 11-year data set. Environmental Science and Technology, 48(9), 47324738. doi: $10.1021 /$ es4053076

Mansui, J., Darmon, G., Ballerini, T., van Canneyt, O., Ourmieres, Y., \& Miaud, C. (2020). Predicting marine litter accumulation patterns in the Mediterranean basin: Spatio-temporal variability and comparison with empirical data. Progress in Oceanography, 182, 102268. doi: 10.1016/j.pocean.2020.102268

Marengo. M., Fullgrabe, L., Fontaine, Q., Mazzotti, N., Lejeune, P., Boissery, P., \& Gobert, S. (2020) Abundance, composition and spatial distribution of marine plastic litter in sea surface waters around Cap Corse. Nanotechnology and Advance Material Science, 3(1), 1-5.

Nash, A. D. (1992). Marine debris and fishing off Irian Jaya. Environment Conservation, 18(1), 80. doi: $10.1017 /$ S0376892900021408

Rees, G. \& Pond, K. (1995). Marine litter monitoring programmes-a review of methods with special reference to national surveys. Marine Pollution Bulletin. 30, 103-108. doi: 10.1016/0025-326X(94) 00192-C

Reinold S, Herrera A, Hernandez-Gonzales C, \& Gomez $M$, (2020). Plastic pollution on eight beaches of Tenerife (Canary Islands, Spain): An annual study. Marine Pollution Bulletin. 151(110847), 1-13. doi: 10.1016/j.marpolbul.2019.110847

Reisser, J., Shaw, J., Wilcox, C., Hardesty, B. D., Proietti, M., Thums, M., \& Pattiaratchi, C. (2013). Marine plastic pollution in waters around australia: characteristics, concentrations, and pathways. Plos One, 8(11), e80466. doi: 10.1371/journal.pone.0080466

Ribeiro, F., Garcia, A. R., Pereire, B. P., Fonseca, M., Mestre, N. C., Fonseca, T. G.,... Bebianno, M.J. (2017). Microplastic effects in Scrobicularia plana. Marine Pollution Bulletin, 15, 122(1-2), 379-391. doi: 10.1016/j.marpolbul.2017.06.078

Rochman, C. M., Tahir, A., Williams, S. L., Baxa, D. V, Lam, S., Miller, J. T., The, F., Werorilangi, S., \& Tee, S. J. (2015). Anthropogenic debris in seafood: Plastic debris and fibers from textiles in fish and bivalves sold for human consumption. Scientific Reports, 5, 14340. doi: $10.1038 /$ srep 14340

Ryan, P. G. (2013). A simple technique for counting marine debris at sea reveals steep litter gradients between the Straits of Malacca and the Bay of Bengal. Marine Pollution Bulletin, 69(1-2), 128-36. doi: 10.1016/ j.marpolbul.2013.01.016

Suaria, G., \& Aliani, S. (2014). Floating Debris in the Mediterranean Sea. Marine Pollution Bulletin, 86(12), 494-504. doi: 10.1016/j.marpolbul. 2014.06.025
Syakti, A. D., Bouhroum, R., Hidayati, N. V., Koenawan, C. J., Boulkamh, A., Sulistyo, I., Lebarillier, S., Akhlus, S., Doumenq, P., \& Wong-Wah-Chung, P. (2017). Beach macrolitter monitoring and floating microplastic in a coastal area of Indonesia. Marine Pollution Bulletin, 122(1-2), 217-225. doi: 10.1016/j.marpolbul. 2017.06.046

Takarina, N. D, \& Adiwibowo, A. (2011). Impact of heavy metals contamination on the biodiversity of marine benthic organisms in Jakarta Bay. Journal of Coastal Development, 14(2), 168-171.

Thiel, M., Bravo, M., Hinojosa, I. A., Luna, G., Miranda, L., Nunez, P., Pacheco, A. S., \& Vasquez, N. (2011). Anthropogenic litter in the SE Pacific: an overview of the problem and possible solutions. Revista de Gestão Costeira Integrada-Journal of Integrated Coastal Zone Management, 11(1), 115-134.

Titmus, A. J., \& Hyrenbach, K. D. (2011). Habitat associations of floating debris and marine birds in the North East Pacific Ocean at coarse and meso spatial scales. Marine Pollution Bulletin, 62(11), 2496-506. doi: 10.1016/j.marpolbul.2011.08.007

UNEP. (2005). Marine Litter, an Analytical Overview. United Nations Environment Programme, Nairobi, Kenya (58p).

UNEP-IMO. (2007). Guidelines for Monitoring Marine Litter on the Seabed of the Northwest Pacific Region. Prepared by NOWPAP and MERRAC.United Nations Environment Programme.

Uneputty, P., \& Evans, S. M. (1997). The impact of plastic debris on the biota of tidal flats in Ambon Bay (eastern Indonesia). Marine Environmental Research, 44(3), 233-242. doi: 10.1016/S0141-1136(97)00002-0

Van Emmerik, T., Loozen, M., van Oeveren, K., Buschman, F., \& Prinsen, G. (2019). Riverine plastic emission from Jakarta into the ocean. Environment Research Letters. 14(8), 084033. doi: 10.1088/1748-9326/ ab30e8

Wilkes, R. A., \& Aristilde, L. (2017). Degradation and metabolism of synthetic plastics and associated products by Pseudomonas sp.: capabilities and challenges. Journal of Applied Microbiology, 123(3), 582-593. doi: 10.1111/jam.13472

Willoughby, N. G. (1986). Man made litter on the shores of the Thousand Islands archipelago. Marine Pollution Bulletin, 17(5), 224-228. doi: 10.1016/0025326X(86)90605-3

Yamashita, R. \& Tanimura, A. (2007). Floating plastic in the Kuroshio Current area, western North Pacific Ocean. Marine Pollution Bulletin 54(4), 464-488. doi: 10.1016/j.marpolbul.2006.11.016 